\title{
O Processo de Redução Temática na Formação de Professores em Iguaí-BA ${ }^{1}$
}

\section{The Reduction Thematic Process in Teacher Training in Iguaí-BA}

\section{Edcleide da Silva Pereira Novais ${ }^{a}$; Kamilla Nunes Fonseca ${ }^{a}$; Ana Paula Solino ${ }^{b}$; Polliane Santos de Sousa ${ }^{c}$; Roger Magalhães da Silva ${ }^{d}$; Simoni Tormohlen Gehlen ${ }^{a}$}

a Universidade Estadual de Santa Cruz, Ilhéus, Brasil - cleideneuro@hotmail.com, mila_nunesf@hotmail.com, stgehlen@gmail.com

b Universidade de São Paulo, São Paulo, Brasil - ana.solino@gmail.com

c Universidade Federal de Santa Catarina, Florianópolis, Brasil - polliane.sds@gmail.com

d Universidade Estadual do Sudoeste da Bahia, Vitoria da Conquista, Brasil - magalhaes_roger@yahoo.com.br

\section{Palavras-chave:}

Tema gerador.

Investigação temática.

Formação de professores.

Paulo Freire.

\section{Keywords:}

Theme generator.

Thematic investigation.

Teacher formation.

Paulo Freire.
Resumo: Investigam-se novas sistematizações da etapa de Redução Temática no contexto de um curso de formação continuada de professores de uma escola municipal de Iguaí-BA, durante o processo de obtenção do Tema Gerador "Para onde vai o lixo do meio rural de Iguaí-BA?". As informações foram obtidas durante este processo de Investigação Temática e a análise foi realizada por meio da Análise Textual Discursiva, em que a Redução Temática foi desenvolvida tendo como referência quatro fases estabelecidas a priori: a) alternativas acerca do problema $e$ implicações socioambientais; b) estruturação do programa escolar a partir das unidades elou subunidades; c) seleção de conhecimentos necessários para compreensão do problema; d) planejamento das aulas a partir dos Momentos Pedagógicos. Dentre os resultados, destaca-se que a estruturação da Redução Temática proporcionou uma análise do ponto de vista conceitual-pedagógico articulada com o Tema Gerador e as fases desenvolvidas nesse processo constituíram vias de problematização junto às professoras, no que se refere ao contato com uma organização curricular baseada em temas.

${ }^{1}$ Trabalho realizado com o auxílio financeiro da CAPES, CNPq e FAPESB. Uma versão preliminar deste estudo foi apresentada no XEncontro Nacional de Pesquisa em Educação em Ciências (ENPEC), 2015. 


\section{Introdução}

Pesquisas na área de educação em ciências têm discutido aspectos relacionados à reestruturação do currículo por meio de temas baseados nas perspectivas do movimento Ciência-Tecnologia-Sociedade (CTS), da Situação de Estudo e da Abordagem Temática Freireana (HALMENSCHLAGER, 2014). Essas propostas apresentam semelhanças ao compreender a importância de atribuir significado ao conhecimento escolar, valorizando as vivências dos estudantes e articulando os conceitos científicos à sua realidade (STRIEDER et al., 2011).

No que se refere à organização curricular por meio de alguns pressupostos freireanos, o currículo escolar é elaborado a partir de um Tema Gerador, relacionado com as denominadas situações-limite ${ }^{2}$ e obtido por meio da Investigação Temática (FREIRE, 1987). Embora a Educação em Ciências não tenha constituído o foco das discussões de Paulo Freire, seus pressupostos têm sido explorados na área com diversos enfoques. Nesse sentido, o processo de Investigação Temática, por exemplo, proposto por Freire (1987), foi sistematizado com algumas adaptações, para o ensino de Ciências, tal como discutido nos estudos de Delizoicov (1982; 1991), São Paulo (1990), Pontuschka (2001), Pernambuco (2001), Silva (2004), Furlan et al. (2011), Lambach (2013), Sousa et al. (2014; 2016), Chagas (2014), Araújo (2015), Auler, N. e Auler (2015), Magalhães e Gehlen (2016) e Centa e Muenchen (2016).

Dentre as etapas da Investigação Temática propostas por Freire (1987), e sistematizadas por Delizoicov $(1982 ; 1991)$, destaca-se a Redução Temática, na qual é realizada a seleção dos conhecimentos científicos necessários para compreensão do tema e a construção do programa escolar a partir da análise relacional da realidade local.

No contexto da pesquisa em educação, parece haver algumas limitações na compreensão desta etapa no desenvolvimento da Investigação Temática. Delizoicov (1991) sinaliza que alguns autores, ao analisarem a perspectiva educacional freireana, desconsideram o processo de Redução Temática e realizam uma interpretação equivocada, a qual, segundo o autor, apresentam visões "espontaneístas" e "reducionistas", sobre as práticas fundamentadas no referencial freireano cuja relevância dos conteúdos específicos nas propostas é minimizada. No entanto, ainda que os conteúdos não constituam o ponto de partida na construção do currículo escolar na perspectiva freireana, estes desempenham papel preponderante para a compreensão do tema (DELIZOICOV, 1991).

Por outro lado, ainda que a etapa de Redução Temática seja fundamental na seleção dos conhecimentos universais enquanto instrumentos para compreensão dos temas,

${ }^{2}$ Freire (1987) compreendia as Situações-limite enquanto situações de injustiça social em que os sujeitos estão imersos de tal maneira que não possuem consciência crítica nem as compreendem como passíveis de superação. 
compreende-se que para a sua efetivação ela necessita estar dialeticamente articulada com a realidade escolar. Nesse sentido, na presente pesquisa investiga-se o despontar de novas sistematizações durante a etapa de Redução Temática efetivada em meio a um curso de formação continuada de professores de uma escola municipal de Iguaí-BA.

\section{O processo de investigação do Tema Gerador e a Redução Temática}

Para o desenvolvimento de uma ação pedagógica que permita valorizar e integrar elementos da identidade sociocultural dos educandos e os conhecimentos científicos, faz-se necessário repensar a organização curricular das escolas. Nesse sentido, as contribuições de Paulo Freire foram importantes para fundamentar a construção de currículos críticos e emancipatórios nos espaços escolares. O processo de investigação do Tema Gerador, por exemplo, foi uma das grandes contribuições para orientar propostas de ensino em diversos municípios do Brasil (SÃO PAULO, 1990; SILVA, 2004).

Esse ato investigativo é baseado no processo de codificação-problematizaçãodescodificação de Freire (1987) e compreende as seguintes etapas: 1) Levantamento Preliminar: consiste no estudo da realidade dos educandos; 2) Codificação: análise e escolha de contradições vividas pelos alunos; 3) Descodificação: nesta etapa, a equipe retorna à comunidade para legitimar as situações-limite na busca pelo Tema Gerador; 4) Redução Temática: escolha dos conceitos científicos e planejamento das atividades.

No Ensino de Ciências, estudos como os de Delizoicov (1982; 1991), Delizoicov et al. (2011) e Silva (2004) têm realizado algumas adaptações do processo de Investigação Temática, em que buscam ampliar a organização da programação curricular e o desvelar do Tema Gerador em sala de aula. Tais adaptações apresentam relações entre si, as quais foram sinalizadas por Torres (2010) no plano teórico e por Sousa et al. (2014) no contexto de um processo formativo de professores de ciências.

Nesse sentido, a Investigação Temática constitui “um processo dinâmico, em que as etapas se intercalam umas nas outras, formando uma rede de significados que auxiliam na obtenção do Tema Gerador" (SOUSA et al., 2014, p. 173), cujas etapas não são estanques, mas atuam auxiliando o processo didático-pedagógico baseado na perspectiva freireana de educação.

Destaca-se que, ao buscar alternativas para o desenvolvimento do processo de Investigação Temática no contexto escolar, sobretudo para o ensino de ciências, Delizoicov (1982; 1991), Delizoicov et al. (2011) e Silva (2004) deixam explícita a importância dos conceitos científicos na organização e no planejamento das atividades didático-pedagógicas, tendo em vista a contribuição destes para a superação das situações-limite vivenciadas pelos 
educandos. Nesse sentido, chama-se atenção para a importância do papel da Redução Temática, no processo de obtenção de Temas Geradores e estruturação de currículos críticos.

A Redução Temática é a última etapa integrante do processo de obtenção de temas, proposto por Freire (1987) e consiste em um trabalho coletivo, em que serão estudadas as informações obtidas nas fases anteriores da investigação temática. Segundo Freire (1987, p. 114) "a sua última etapa [da Investigação Temática] se inicia quando os investigadores, terminadas as descodificações nos círculos, dão começo ao estudo sistemático de seus achados". Nesse momento, são selecionados os conhecimentos/conteúdos que serão necessários para a compreensão do tema. Nas palavras do autor:

[...] feita a delimitação temática, caberá a cada especialista, dentro de seu campo, apresentar à equipe interdisciplinar o projeto de "redução" do tema. No processo de "redução" deste, o especialista busca os seus núcleos [...] fundamentais que, constituindo-se em unidades de aprendizagem e estabelecendo uma seqüência entre si, dão a visão geral do tema "reduzido" (FREIRE, 1987, p. 115).

No contexto escolar, esses especialistas podem ser representados pelos educadores de diferentes áreas de conhecimentos que, em planejamento coletivo e interdisciplinar, selecionam quais conhecimentos de sua área serão necessários e potencializadores para o entendimento do Tema Gerador em estudo.

Freire afirma que os temas jamais deverão ser tratados esquematicamente, “esvaziando-se na estreiteza dos especialismos" (FREIRE, 1987, p. 133). Em outras palavras, o olhar específico dado por cada especialista significa uma visão mais detalhada do tema, que se complementa no conjunto de toda unidade programática. Desta forma, os critérios utilizados durante a Redução Temática são epistemológicos, isso porque os conhecimentos científicos são previamente selecionados e estruturados antes de serem desenvolvidos em sala de aula, "constituindo conteúdos programáticos escolares críticos e dinâmicos" (DELIZOICOV, 1991, p. 181).

Tendo em vista o desafio de aliar a profundidade na abordagem dos problemas e a perspectiva interdisciplinar, sem recair em pseudo-especialidades, Delizoicov et al. (2011) propõem o uso de conceitos unificadores enquanto referencial para seleção dos conteúdos. Os Conceitos Unificadores são assim denominados por minimizar a fragmentação dos conteúdos e permitir uma articulação entre as partes e o todo. Tais conceitos são também supradisciplinares, pois "permeiam os escopos da Física, Química, Biologia, Geologia, Astronomia" (ANGOTTI, 1983, p. 196), sem descaracterizar as especificidades de cada área do conhecimento. Considerando aspectos da investigação da comunidade, constituem alternativa para contemplar a realidade local, as especificidades de cada área do conhecimento, sem fragmentações, e o desenvolvimento cognitivo dos educandos (SÃO PAULO, 1992). 
Contribuindo para a adaptação do processo de Investigação Temática para o contexto escolar, Silva (2004) também realiza aprofundamentos em suas etapas a partir de um estudo teórico-prático. Com relação à etapa de Redução Temática o autor propõe a construção do programa escolar via Tema Gerador por meio de Falas Significativas da comunidade sobre uma determinada situação-problema, a qual precisa ser entendida com o intuito de superar contradições existentes dentro de um contexto. Segundo o autor, as Falas Significativas expressam implícita ou explicitamente algum limite explicativo referente às contradições da realidade concreta dos sujeitos, isto é: "na trama das falas significativas e monológicas está a revelação dos conflitos e tensões da prática pedagógica reificada” (SILVA, 2004, p. 18).

A organização curricular para Silva (2004) ocorre por meio da construção de uma Rede Temática, que sintetiza as diferentes compreensões da realidade investigada, não havendo sobreposição entre as visões de mundo dos educadores e da comunidade. Nesta rede é apresentada uma síntese da análise relacional e contextualizada da realidade local em diferentes dimensões, que busca compreender historicamente as imbricações da realidade concreta e delinear critérios ético-críticos e político-epistemológicos para a construção das programações (SILVA, 2004).

Sendo assim, Silva (2004) acrescenta novos elementos ao processo de Redução Temática, ampliando teórico-metodologicamente este processo, tal como o Contratema que representa uma antítese do Tema Gerador. Isto é, os Contratemas representam a compreensão do educador, a partir dos conhecimentos universais sistematizados, das situações significativas contidas nas contradições. Em outras palavras, o Contratema é "uma bússola norteadora da síntese analítica/propositiva, desveladora da realidade local que se pretende construir com os educandos, na perspectiva da intervenção na realidade imediata" (SILVA, 2004, p. 213).

Com base nas contribuições de Delizoicov et al. (2011) e Silva (2004), cabe salientar que para Freire (1987) no fluxo da investigação a equipe de especialistas e o povo constituem sujeitos da mesma. Isto é, durante o processo de codificação-problematização-descodificação envolvido na investigação, aos sujeitos envolvidos é proporcionada a atmosfera para a "(re) ad-miração" das situações significativas vivenciadas, permitindo apreendê-las como campo de sua ação e reflexão (FREIRE, 1983).

Nesse sentido, compreende-se que, enquanto espaço de diálogo, de constituição de sujeitos, de inserção crítica na realidade, a dinâmica proporcionada pela investigação temática, a partir da relação dialética entre os sujeitos envolvidos e entre os sujeitos e a realidade, possibilita o re-fazer da prática, a constituição da práxis e o delineamento de novas sistematizações do próprio processo de investigação do tema a partir das necessidades imanentes da prática. Tal aspecto constitui o epicentro do presente trabalho, cuja discussão 
encontra-se centrada na etapa de Redução Temática, dada a sua relevância para a instituição do programa escolar. Sendo assim, a seguir será explicitado o desenvolvimento da Investigação Temática no contexto de um curso de formação de professores tendo em vista explicitar a constituição de novas sistematizações e a reconfiguração da Redução Temática a partir do trabalho coletivo.

\section{Encaminhamento metodológico}

Com o intuito de melhor compreender a constituição do processo de Redução Temática enquanto práxis, investigou-se o despontar de novas sistematizações na estruturação de um programa escolar, pautado em um Tema Gerador, com professores de uma escola municipal do campo, localizada em Iguaibí, distrito do município de Iguaí, interior do Sul da Bahia.

A escola em que foi realizada a investigação contém cerca de 220 (duzentos e vinte) alunos provenientes de várias regiões do meio rural de Iguaí, e foi escolhida pelo fato da autora principal deste estudo morar no referido município e atuar como docente da escola. $\mathrm{O}$ curso intitulado "O Ensino de Ciências nas escolas do campo de Iguaí-Ba: um olhar sobre a construção do currículo" foi promovido no segundo semestre de 2014, no período de outubro até dezembro, mediante parceria estabelecida entre duas professoras de ciências da escola e o Grupo de Estudos sobre Abordagem Temática no Ensino de Ciências $\left(\right.$ GEATEC $\left.^{3}\right)$ da Universidade Estadual de Santa Cruz (UESC).

O curso foi organizado em 6 (seis) encontros, totalizando uma carga horária de 40 (quarenta) horas, dos quais dois ocorreram nas dependências da UESC e quatro na escola, no horário das Atividades Complementares ${ }^{4}$, sob a orientação de um dos integrantes do GEATEC. Na UESC, os encontros tiveram como foco a discussão de aspectos teóricometodológicos articulados ao planejamento das atividades didático-pedagógicas relacionadas ao Tema Gerador e na escola as professoras discutiram e sistematizaram as aulas.

As informações para análise foram obtidas por meio de videogravações dos encontros realizados com as professoras, dos questionários respondidos pelos alunos da escola e de falas de moradores obtidas por meio das atividades do Plano Municipal de Saneamento Básico de Iguaí. As falas foram identificadas por códigos alfanuméricos: A1, A2, A3,....An para as falas dos alunos; M1, M2,..., Mn para as falas dos moradores e P1, P2 e P3 para as falas das

\footnotetext{
${ }^{3}$ O GEATEC é composto por alunos de Iniciação Científica da área de Física, mestrandos do Programa de PósGraduação em Educação em Ciências (PPGEC/UESC), das áreas de Pedagogia, Biologia e Química, uma doutoranda em Educação da área de Pedagogia, uma doutoranda em Educação Científica em Tecnológica da área da Física, professores da Rede Estadual de Ensino de Ilhéus da área de Física e a professora coordenadora da área de ensino de Física da UESC.

${ }^{4}$ As atividades complementares referem-se ao momento de planejamento e organização de atividades na escola, as quais ocorrem uma vez por semana.
} 
professoras. A análise foi realizada por meio da Análise Textual Discursiva (ATD) (MORAES; GALIAZZI, 2007), que é uma ferramenta de análise qualitativa constituída por uma sequência recursiva de três componentes: a unitarização, a categorização e a construção de texto argumentativo-interpretativo (metatexto).

O corpus desta pesquisa compreende as informações obtidas pela videogravação dos encontros com as professoras. A unitarização caracteriza-se pela desconstrução do corpus em unidades de significados, que nesta pesquisa constituíram fragmentos de informações referentes ao desenvolvimento das fases da Redução Temática. A categorização consiste num processo de agrupamento das unidades de significados em grupos de sentidos semelhantes denominados por categorias, as quais podem emergir da análise dos dados (categorias $a$ posteriori) ou ser previamente (categorias a priori) estabelecidas de acordo com o que se pretende investigar (MORAES; GALIAZZI, 2011). Desta forma, o processo de categorização estruturou-se por meio de quatro categorias a priori: quais sejam: a) Alternativas acerca do problema e implicações socioambientais, b) Estruturação do programa escolar a partir das unidades e/ou subunidades; c) Seleção de conhecimentos necessários para compreensão do problema; d) Planejamento das aulas a partir dos Momentos Pedagógicos.

\section{Obtenção do Tema Gerador em uma escola em Iguaí-BA}

O processo de obtenção do Tema Gerador, bem como a organização das atividades didático-pedagógicas, foi estruturado com base nas adaptações das etapas de Sousa et al. (2014), sistematizadas mediante a articulação entre a Abordagem Temática Freireana (DELIZOICOV et al., 2011) e a Práxis Curricular via Tema Gerador (SILVA, 2004), sejam elas:1) Aproximações iniciais com a comunidade local e escolar; 2) Apresentação de possíveis situações-limite para a comunidade local; 3) Legitimação da hipótese de situaçãolimite e 4) Organização da programação curricular, as quais serão explicitadas a seguir.

1) Aproximações iniciais com a comunidade local e escolar: Nessa etapa, os integrantes do GEATEC buscaram aproximações com o contexto escolar para melhor compreender a realidade a ser estudada. Buscou-se conhecer o entorno escolar, bem como aspectos característicos da comunidade. Essas informações foram obtidas por meio dos seguintes instrumentos:

i) questionários que foram aplicados a 36 (trinta e seis) alunos dos anos iniciais do ensino fundamental da escola. As questões estavam relacionadas com possíveis situaçõesproblema vivenciadas pela comunidade escolar, identificadas pela primeira autora deste 
trabalho que mora no distrito de Iguaibí e trabalha na escola, referentes a visões ${ }^{5}$ que os mesmos apresentavam sobre o consumo de água, o local onde moram e o descarte do lixo; ii) conversas informais: realizadas com os moradores locais a fim de conhecer os problemas que a comunidade do meio rural de Iguaí vivencia;

iii) imagens que foram obtidas pela equipe de elaboração do Plano Municipal de Saneamento Básico ${ }^{6}$ (PMSB) no distrito de Iguaibí, do qual a autora principal deste estudo fez parte, as quais representavam situações significativas vivenciadas pela comunidade.

As informações obtidas foram analisadas pelos integrantes do GEATEC com o objetivo de conhecer algumas situações significativas presentes na comunidade.

2) Apresentação de possíveis situações-limite para a comunidade local: De posse das informações obtidas na etapa anterior, foi possível identificar hipóteses de situações-limite vivenciadas pelos moradores do meio rural de Iguaí e alunos da escola, os quais apresentavam uma visão superficial e acrítica sobre os seguintes aspectos: descarte do lixo, tendo em vista que os moradores buscam diversas alternativas para o descarte do lixo no meio rural; e uso indiscriminado da água, principalmente relacionado à falta de tratamento. Essas hipóteses foram consideradas no planejamento de uma história em quadrinhos denominada "Conhecendo o meio rural de Iguaí-BA", a qual foi elaborada contendo algumas das respostas dos alunos obtidas através dos questionários. A história em quadrinhos configurou-se como uma codificação, que sistematizou as hipóteses de situações-limite com os alunos.

3) Legitimação da hipótese de situação-limite: Os integrantes do GEATEC retornaram à comunidade para apresentar as hipóteses de situações-limite anteriormente identificadas, com o intuito de aprofundar as compreensões que eles apresentavam sobre um determinado problema presente em sua realidade. No contexto da comunidade de Iguaibí, essa etapa foi realizada em dois momentos:

i) com os alunos no desenvolvimento da história em quadrinhos, conforme discutido anteriormente, em que novos conhecimentos sobre a situação vivenciada foram identificados, enriquecendo as informações sobre as hipóteses de tema;

ii) com as professoras durante o curso de formação, em que foram apresentadas às educadoras falas de alunos e moradores, agrupadas segundo as hipóteses de situaçõeslimite, quais sejam: o consumo indiscriminado da água, visão superficial da realidade e descarte do lixo.

\footnotetext{
${ }^{5}$ Cabe ressaltar que algumas visões que os alunos e a comunidade local apresentavam sobre o seu entorno eram de conhecimento do GEATEC, porque um dos integrantes do grupo faz parte desta comunidade. Esse conhecimento foi importante para ajudar a estruturar o questionário.

${ }^{6}$ Concomitantemente a realização desta pesquisa, iniciou-se o planejamento do Plano Municipal de Saneamento Básico (PNSB) que é organizado pela FUNASA e o CREA-BA, projeto desenvolvido pelo Programa Sanear Mais Bahia.
} 
Com a apresentação das codificações para os alunos e professoras foi possível legitimar a hipótese de situação-limite relacionada ao descarte acrítico do lixo na região, como sinalizam as falas presentes na Tabela 1 que expressam uma compreensão acrítica do problema, sinalizando uma acomodação ao mesmo.

Tabela 1: Situações-limite relacionadas ao Tema Gerador.

\begin{tabular}{|c|c|c|}
\hline Situações-limite & $\begin{array}{c}\text { Falas - Moradores (M), Professores (P) e } \\
\text { Alunos (A) }\end{array}$ & Comentários \\
\hline $\begin{array}{l}\text { 1. A queima do } \\
\text { lixo é vista como } \\
\text { solução }\end{array}$ & $\begin{array}{l}\text { Para não ficar espalhado porque não tem } \\
\text { coleta (M5) } \\
\text { Porque não tem ninguém pra pegar (A2) }\end{array}$ & $\begin{array}{l}\text { As falas expressam a dificuldade } \\
\text { que os moradores apresentam em } \\
\text { relação ao descarte do lixo, como } \\
\text { não há coleta optam por queimá-lo, } \\
\text { não considerando os malefícios que } \\
\text { essa ação pode causar para o meio } \\
\text { ambiente. }\end{array}$ \\
\hline $\begin{array}{l}\text { 2. Compreensão } \\
\text { acrítica do } \\
\text { problema }\end{array}$ & $\begin{array}{l}\text { A queima do lixo próximo às casas na } \\
\text { chegada do distrito, onde existem casas a } \\
\text { menos de } 15 \text { metros, as pessoas também } \\
\text { colocam animais e a queima do lixo polui } \\
\text { o ar causando muitas dores de cabeça e } \\
\text { doenças respiratórias (M5). } \\
\text { Quando eles queimam o lixo, as moscas } \\
\text { correm para as casas (P2). }\end{array}$ & $\begin{array}{l}\text { As falas aqui elencadas mostram } \\
\text { que embora os moradores optem } \\
\text { pela queima do lixo como uma } \\
\text { forma de descarte, alguns } \\
\text { moradores } \\
\text { reconhecem o perigo que esta } \\
\text { alternativa traz para os seres } \\
\text { humanos. }\end{array}$ \\
\hline $\begin{array}{l}\text { 3. Acomodação ao } \\
\text { problema }\end{array}$ & $\begin{array}{l}\text { Porque não tem ninguém pra pegar (A2) } \\
\text { Não tem um lugar apropriado para jogar o } \\
\text { lixo (M7) } \\
\text { O meu lixo também vai para esse lugar } \\
\text { (rio), também sei que é errado, mas não } \\
\text { tem outro para jogar (P1) } \\
\text { Culpado é a prefeitura que paga pra jogar } \\
\text { ai (A2) }\end{array}$ & $\begin{array}{l}\text { As falas indicam que alguns } \\
\text { moradores, professores e alunos } \\
\text { eximem-se de sua responsabilidade } \\
\text { com o descarte do lixo, atribuindo-a } \\
\text { apenas ao Poder Público. }\end{array}$ \\
\hline
\end{tabular}

Fonte: Autores

A legitimação da situação-limite permitiu a identificação do Tema Gerador "Para onde vai o lixo do meio rural de Iguaí-BA?", relacionado ao descarte do lixo na zona rural do município. Com isso, os integrantes do GEATEC, inspirados na proposta de Silva (2004), sistematizaram as falas significativas da comunidade em forma de uma Rede Temática, a fim de apresentar uma visão geral das situações significativas apontadas pela comunidade e as possíveis formas de superação a partir da visão dos educadores. A figura 1 representa uma adaptação da Rede Temática sobre o Tema Gerador, tendo como referência alguns aspectos do estudo de Silva (2004), em especial o Contratema, a Situação-Problema e a Questão Geradora. 


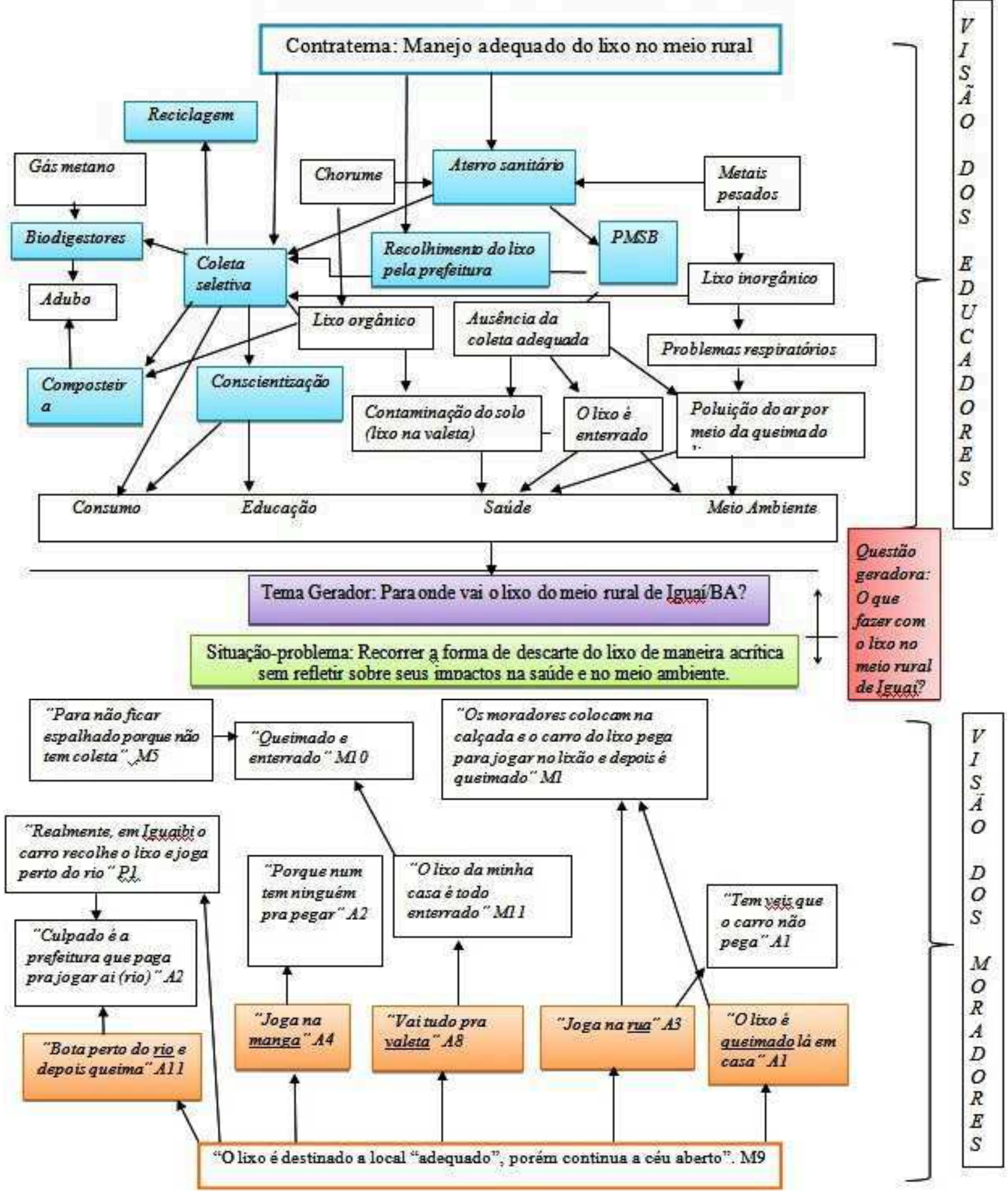

Figura 1: Rede Temática adaptada de Silva (2004): "Para onde vai o lixo do meio rural de Iguaí-BA". Fonte: Autores.

Para Silva (2007), a Rede Temática é uma representação concreta do conhecimento relacional apreendido, sistematizada por meio do diálogo entre os envolvidos na construção da prática educativa. $\mathrm{O}$ autor ressalta que a leitura da Rede Temática deve ser realizada de baixo para cima, do local (visão dos moradores) para o macroestrutural (visão dos educadores). Essa leitura é guiada pela visão dos educadores, que a partir da análise das falas 
significativas escolhem quais conhecimentos, práticas e ações são necessários para compreender o problema identificado, junto à comunidade.

Ao analisar as implicações do descarte do lixo, os educadores sugeriram possíveis alternativas para o descarte e contribuíram para eleger o Contratema: "Manejo adequado do lixo no meio rural". Para Silva (2004), o Contratema é uma resposta para a Questão Geradora, a qual, neste estudo, compreende "O que fazer com o lixo do meio rural de Iguaí?”. Ressalta-se que as alternativas sugeridas pelos educadores são passíveis de realização tanto pelo poder público quanto pela comunidade. Por exemplo, a coleta seletiva pode ser realizada pela comunidade com a construção de composteiras para produção de adubo e mediada pelo poder público incentivando práticas de reciclagem. Nesse sentido, também fazem parte desta etapa da Rede Temática práticas e ações que necessitam ser desenvolvidas com intervenções das Políticas Públicas que são fundamentais para a compreensão e superação de um problema, bem como pela ação coletiva da comunidade, em que o enfrentamento do problema não recaia apenas em ações individuais (AULER, N.; AULER, 2015).

Segundo Silva (2004), durante a síntese das discussões os esboços da programação são sinalizados. Nesse sentido, após a construção da Rede Temática, os integrantes do GEATEC organizaram um Ciclo Temático (SOLINO, 2013; MAGALHÃES, 2015) que tem como objetivo sistematizar a visão dos educadores presente no topo da Rede Temática, em que cada fase foi elaborada por meio de problematizações que serviram para o direcionamento da Redução Temática. Ciclo Temático foi dividido em três fases: $1^{\mathrm{a}}$ - Formas de descarte; $2^{\mathrm{a}}$ Implicações e $3^{\mathrm{a}}$ - Manejo adequado do lixo, tal como apresenta a Figura 2. 


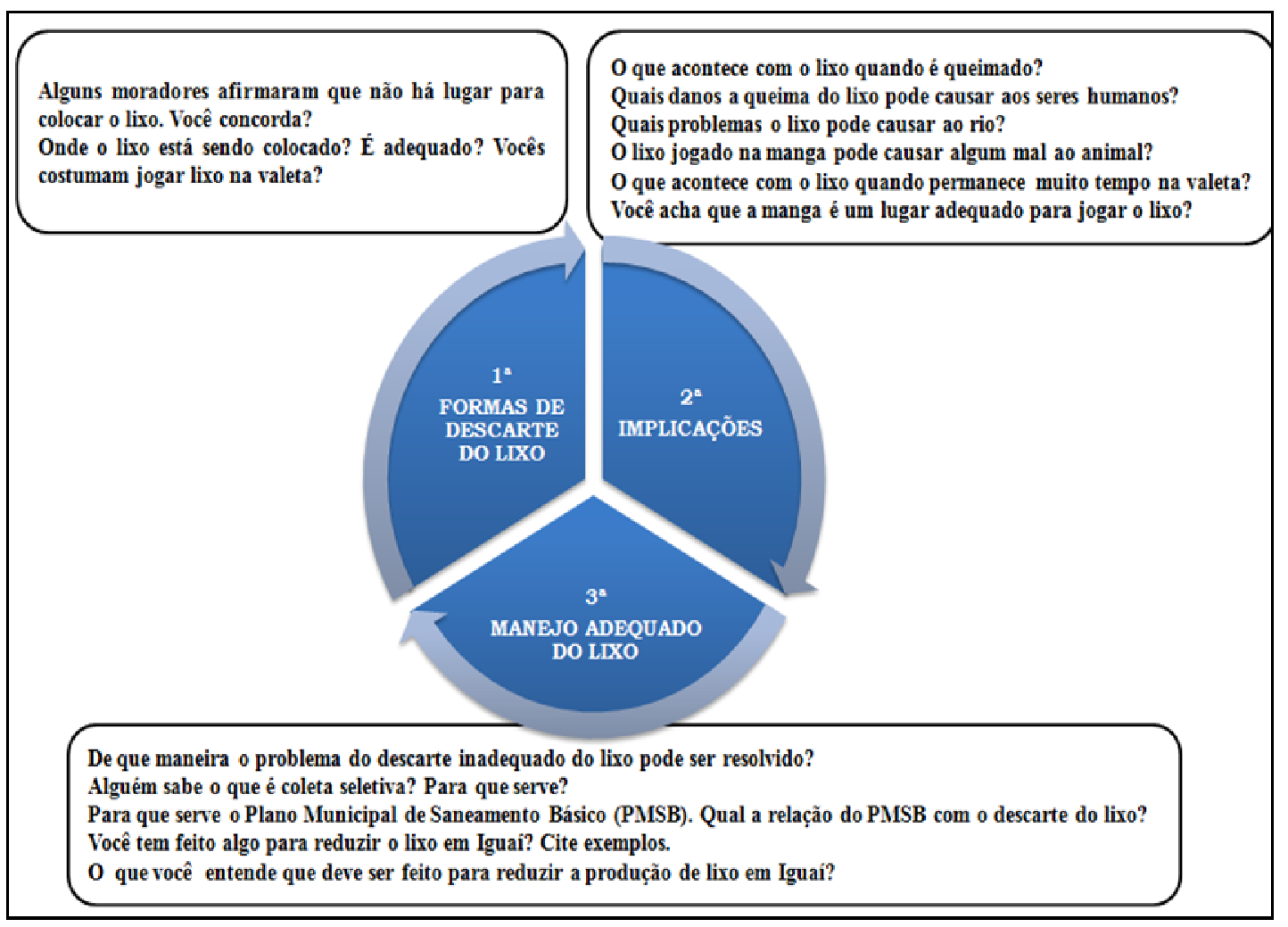

Figura 2: Ciclo Temático construído para sistematizar alguns aspectos da Rede Temática. ${ }^{7}$ Fonte: Autores

A organização do Ciclo Temático seguiu uma lógica, iniciando pelas formas de descarte, com a finalidade de problematizar a relação dos sujeitos do campo com a questão do lixo e a compreensão acerca da natureza e do meio ambiente. Por meio da fase denominada implicações foram analisadas as alternativas de descarte do lixo, sinalizando os efeitos que o descarte inadequado traz para a fauna, flora e seres humanos. A fase do manejo adequado do lixo propõe além de discussões relacionadas ao consumo do lixo, alternativas para amenizar os impactos causados pelo descarte inadequado do mesmo, discutidos na primeira fase. Essas alternativas são ações que envolvem o coletivo, isto é, toda a comunidade escolar bem como o poder público, conforme já destacado. Para Auler, N. e Auler (2015), as ações apenas individuais são frágeis se o objetivo for um real enfrentamento dos problemas socioambientas. Aqui vale destacar a importância que Freire atribui à co-participação dos sujeitos: "o sujeito pensante não pode pensar sozinho; não pode pensar sem a co-participação de outros sujeitos no ato de pensar sobre o objeto. Não há um "penso”, mas um "pensamos. É o "pensamos" que estabelece o "penso" e não o contrário" (FREIRE, 2002, p. 66).

4) Organização da programação curricular: Após a construção da Rede Temática e do Ciclo Temático, os integrantes do GEATEC em conjunto com as professoras da escola, realizaram o

${ }^{7}$ No Ciclo Temático, os termos "manga" e "valeta" são expressões regionais que os moradores utilizam para se referir, respectivamente, ao local no qual os animais se alimentam (pasto) e a um buraco no chão que serve de depósito para o lixo. 
processo de Redução Temática, o qual se refere à escolha e organização de conteúdos, conceitos científicos, conhecimentos e práticas, bem como o planejamento de aulas, necessários para a compreensão e superação dos problemas subjacentes ao Tema Gerador. No decorrer desse processo foi possível evidenciar um movimento composto por quatro fases, as quais foram organizadas em categorias a priori e serão discutidas e analisadas a seguir.

\section{Fases do processo de Redução Temática}

Realizou-se o processo de Redução Temática por meio da efetivação de quatro fases: a) Alternativas acerca do problema e implicações socioambientais; b) Estruturação do programa escolar a partir das unidades e/ou subunidades; c) Seleção de conhecimentos necessários para compreensão do problema; d) Planejamento das aulas a partir dos Momentos Pedagógicos. Para a análise do desenvolvimento dessas fases, utilizou-se a ATD para estabelecer cada fase da Redução Temática como uma categoria analítica estabelecida $a$ priori. Desta maneira, nesta pesquisa, a construção do texto interpretativo-argumentativo - o metatexto - de cada categoria (MORAES; GALIAZZI, 2011), foi redigida de maneira a conjugar a explicitação do processo desenvolvido com os resultados das análises realizadas em cada fase da Redução Temática.

\section{Alternativas acerca do problema e implicações socioambientais}

Após a seleção do Tema Gerador foram discutidos, pelo GEATEC e pelas professoras, os principais aspectos relacionados aos problemas de descarte do lixo na comunidade local. Para isso, falas de alunos e moradores, representativas de situações-limite e obtidas durante o processo inicial da Investigação Temática, foram reanalisadas, com o intuito de evidenciar práticas relacionadas às formas de descarte do lixo utilizadas pela comunidade para serem problematizadas e incluídas na programação de ensino.

Em conversa com as professoras durante o processo de Redução Temática, foi resgatada a fala de um aluno que culpou a prefeitura da cidade por jogar o lixo na margem do rio que corta o distrito de Iguaibí. Ao analisar esta fala, a professora P1 esclareceu que o aluno culpou a prefeitura porque a comunidade já havia solicitado um local apropriado para o descarte do lixo afirmando que "a comunidade já percebeu que é um problema jogar o lixo na beira do rio, mas nada foi feito" (P1).

Essa discussão levou o grupo de pesquisadores a perceber que mesmo reconhecendo a inadequação do descarte de lixo da cidade, parece haver certa acomodação não só da comunidade, mas também das professoras a respeito dessa prática. Isso fica claro quando P1 afirma que: "o meu lixo também vai para esse lugar (rio), também sei que é errado, mas não tem outro para jogar". Embora tenham consciência de que é "errado" e que traz 
consequências negativas para o meio ambiente, a alternativa que encontram é continuar descartando o lixo em lugares inadequados.

Outras alternativas de descarte mencionadas pelos moradores e alunos da escola foram resgatadas nesta primeira fase da Redução Temática, tais como: “Joga na manga [pasto]” A4; "[...] Bota no lixo e depois queima" A12; "Os moradores colocam na calçada e o carro pega para jogar no lixo e depois é queimado" (M12); "bota perto do rio e depois queima” (A11); "Na rua” (A8). Ao colocar em discussão essas alternativas, uma das professoras reclama quando há queimadas de lixos próximos da sua casa, afirmando que: "quando eles queimam o lixo, as moscas correm para as casas” (P2). Isso parece evidenciar certa preocupação da professora em relação à saúde da população, tendo em vista que a proliferação de moscas pode causar doenças.

Deste modo, as professoras e o grupo de pesquisadores analisaram as implicações que estas alternativas poderiam causar para a saúde e ao meio ambiente. Percebeu-se que as consequências que envolvem as alternativas que a comunidade apresenta para o descarte do lixo estão intrinsecamente ligadas aos animais, ao ser humano, a água e ao solo. Essa percepção é mencionada pelas professoras ao relembrarem situações vivenciadas por elas:

\footnotetext{
Lá mesmo, onde meu pai tem uma terrinha, os moradores jogam lixo na manga. Quando eu tava lá achava tudo normal porque eu não tinha conhecimento (P2).

Muitos animais morrem por ingerir sacos de salgadinhos (P1).
}

Com base nessas discussões realizadas com as professoras em torno da análise das falas de alunos e moradores, direcionadas à questão do lixo na comunidade e suas alternativas para o descarte, foi construído um quadro síntese. Para essas respectivas "soluções", traduzidas nas ações e atitudes da comunidade, as professoras apontaram algumas implicações para o meio ambiente, percebidas pelo coletivo naquele momento, as quais estão diretamente atreladas aos animais, à água, ao ser humano e ao solo, conforme Quadro 1 a seguir. 
Quadro1: Primeira fase do processo de Redução Temática.

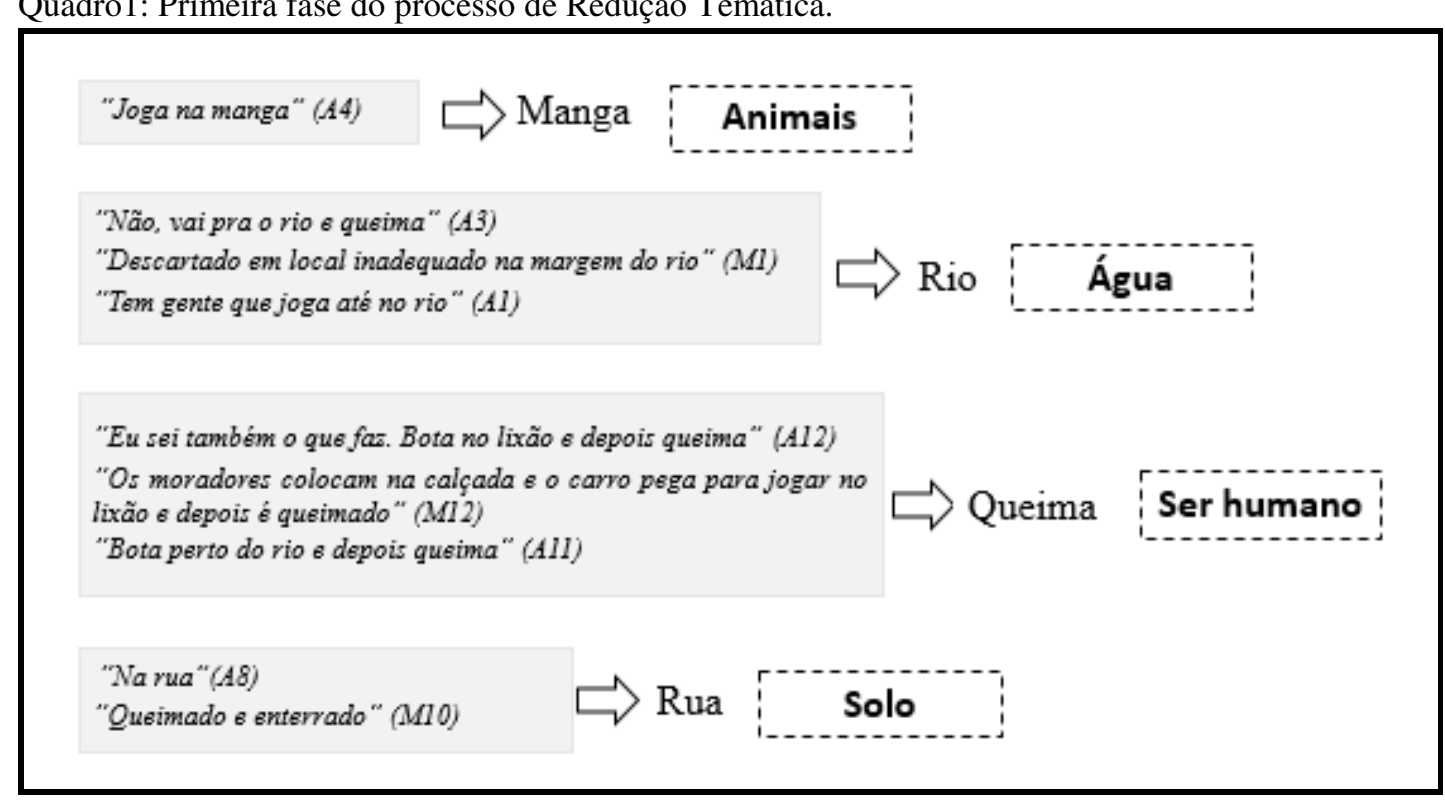

Fonte: Autores

Essa discussão das relações entre o problema de descarte do lixo na comunidade e suas implicações para a natureza direcionaram a visão das professoras e do grupo para o reconhecimento de uma abordagem interdisciplinar no trabalho pedagógico deste problema. Nesse contexto, uma das professoras afirmou que: "é muito bom [o trabalho interdisciplinar], pois permite a interação entre todas as disciplinas”. (P2). Sendo assim, a importância dada pelas professoras, em especial por P2, ao trabalho interdisciplinar, sinalizam que a interação entre disciplinas e o trabalho coletivo precisam ser abordados no currículo, pois, ações colaborativas potencializam a possibilidade de superação das situações-limite, partindo do pressuposto de que a complexidade das questões requer a análise sob vários ângulos (MUENCHEN; AULER, 2007). No contexto do curso desenvolvido, essas relações são feitas em colaboração com o GEATEC, que em sua organização é formado por um coletivo de especialistas de diversas áreas que juntos possuem um objetivo em comum, o qual seja elaborar materiais didáticos-pedagógicos em colaboração com professores da educação básica, tendo como pano de fundo, o diálogo e a aproximação entre a universidade e a escola.

Assim, a primeira fase da Redução Temática consistiu no agrupamento de falas significativas, de alunos e moradores, em torno de possíveis soluções que os alunos e a comunidade local apresentavam para o descarte do lixo no meio rural, bem como as suas implicações para os animais, rio, ser humano e o solo. Constata-se que essas concepções estão apoiadas apenas no descarte do lixo, “onde colocar o lixo?” sem que em nenhum momento, os alunos, moradores e professoras apresentaram aspectos que direcionassem alguma discussão quanto à produção do lixo, isto é, da necessidade de reduzir o lixo, da poluição, aspectos fundamentais quando se pensa em enfrentar problemas socioambientais (AULER, N.; AULER, 2015). Essas falas, portanto, representam a visão de mundo da comunidade e das 
professoras em relação às contradições sociais que vivenciam. Silva (2004) ressalta que a análise das falas significativas da comunidade propicia identificar suas concepções reversas, reveladoras das contradições sociais. Sendo assim, essas manifestações de contradições apontam para situações-limite, situações que impedem os sujeitos de analisarem a sua realidade para além do conhecimento compartilhado socio-historicamente pela comunidade local (FREIRE, 1987).

\section{Estruturação do programa escolar em unidades e/ou subunidades}

Com base nas discussões anteriores, as professoras e os integrantes do GEATEC deram continuidade ao processo de Redução Temática buscando agrupar os elementos expressos no Quadro 1 em duas unidades, quais sejam: i) descarte do lixo e suas implicações; ii) manejo dos resíduos sólidos e possíveis soluções, tal como apresenta o Quadro 2.

Conforme consta no Quadro 2, a Unidade I "Descarte do lixo e suas implicações" foi estruturada em quatro subunidades: manga, rio, rua e queima. As subunidades, por sua vez, foram organizadas com base nas implicações para saúde e meio ambiente de cada tipo de descarte, por exemplo, o descarte do lixo na manga traz implicações para os animais uma vez que os mesmos podem se alimentar do lixo, como sacolas plásticas que são jogadas no pasto.

A Unidade II "Manejo dos resíduos sólidos e possíveis soluções", a qual não foi identificada em falas de moradores e alunos, tem como foco o manejo dos resíduos sólidos em que é importante trabalhar a coleta seletiva do lixo, separando o lixo seco do orgânico, e a construção de uma composteira. 
Quadro 2: Segunda fase da Redução Temática.

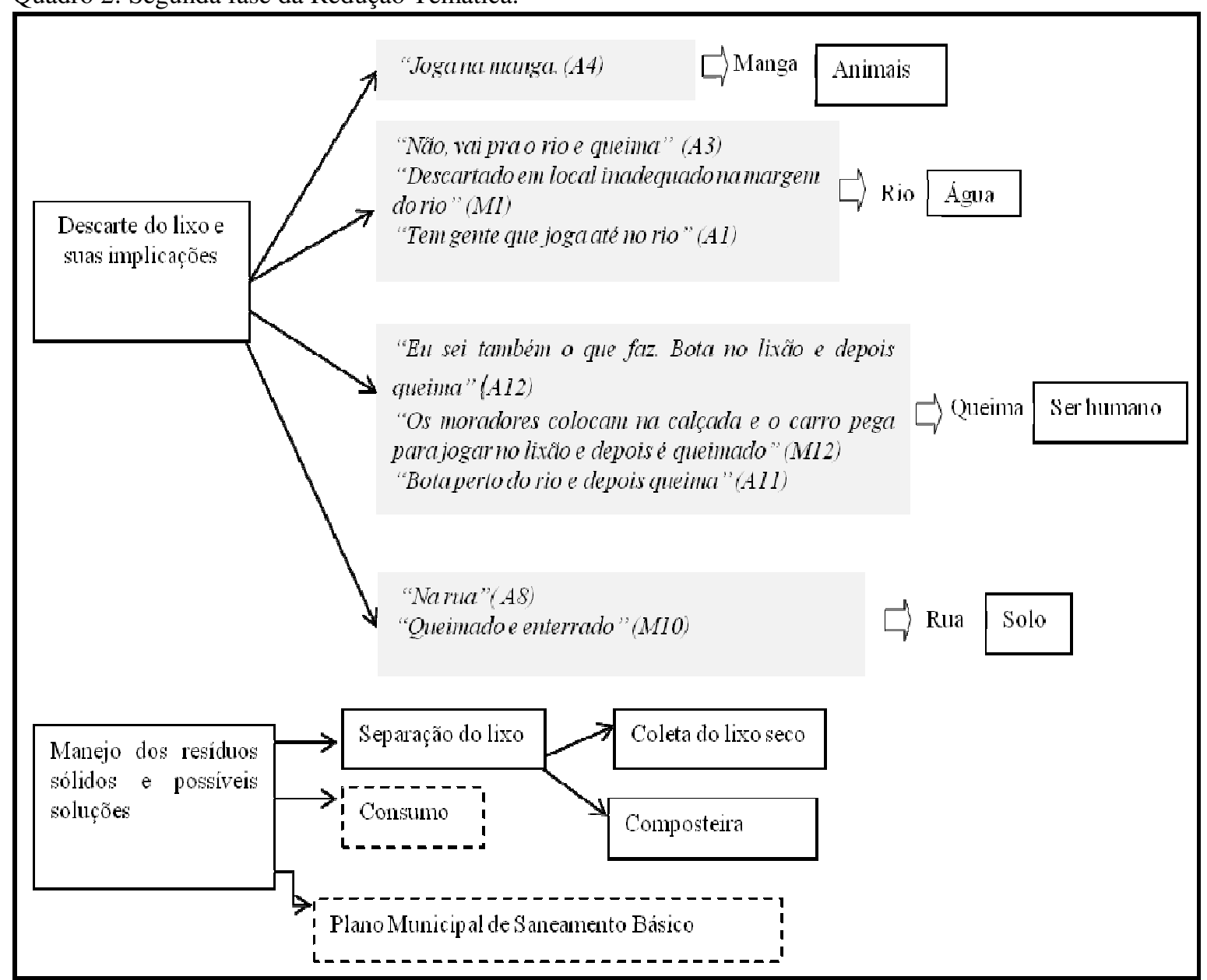

Fonte: Autores

Essas unidades foram construídas em conjunto com as professoras durante a Redução Temática, razão pela qual as professoras destacaram que:

Essas unidades são importantes porque tratam da realidade que os alunos vivenciam. Eles se identificarão com o que vai ser trabalhado (P1).

Abordar o descarte do lixo é importante porque o lixo é jogado de qualquer jeito e de qualquer forma (P2).

As professoras P1 e P2 mencionaram que é importante discutir aspectos da realidade dos alunos para que eles se identifiquem com o problema, no entanto, se identificar com o problema não garante uma transformação da realidade, assim como, abordar o problema em sala de aula. É necessário que as situações-limite presentes no problema sejam problematizadas junto aos estudantes, para que estes possam mobilizar-se a conhecer e se apropriar de novas alternativas para o problema em questão, de modo a potencializar o trânsito da consciência real efetiva sobre o problema, para uma consciência máxima possível (FREIRE, 1987).

O caráter problematizador da educação freireana, oportuniza o movimento de reflexão contínua entre o fazer e o pensar, por isso problematizar as concepções envolvidas, tanto dos 
alunos quanto das professoras, é fundamental na construção de novos conhecimentos. Nesse sentido, após a etapa do curso de formação em que foram organizadas essas unidades, constatou-se a necessidade de colocar na programação das aulas alguns aspectos que são fundamentais para serem problematizados em discussões relacionadas ao descarte do lixo, a exemplo do Consumo deste lixo e algumas ações políticas como o Plano Municipal de Saneamento Básico (PMSB) da cidade, motivo pelo qual constam pontilhados no Quadro 2.

\section{Seleção de conhecimentos necessários para compreensão do problema}

Por meio da sistematização apresentada no Quadro 2 foram selecionados alguns conhecimentos necessários para melhor compreender o tema no contexto das aulas de ciências. Os conceitos selecionados estavam relacionados à disciplina de Física, tais como densidade do ar, calor e temperatura; Química: combustão, misturas homogêneas e heterogêneas, chorume; Educação Ambiental: contaminação do solo pelo lixo orgânico, reciclagem, coleta seletiva e composteira; e Biologia: sistema digestivo dos bovinos e organismos decompositores. O Quadro 3 apresenta os principais conhecimentos que foram selecionados a partir da sistematização das falas.

Ao selecionar os conteúdos, P1 destaca:

A partir do tema a gente pode encaixar os conteúdos que vem na grade curricular.
Os conteúdos foram encaixados dentro desse problema que identificamos (P1 - grifo
nosso).

Há indicativos de que a professora P1 compreendeu a proposta freireana de educação baseada na abordagem de temas, em que os conteúdos são "encaixados" para compreender o problema e não o contrário - quando o ensino é baseado na lógica da abordagem conceitual em que os problemas estão subordinados aos conteúdos curriculares. Apropriar-se dessa discussão é fundamental, principalmente no contexto da Redução Temática, já que a lógica temática é o princípio estruturante da seleção de conteúdos e conceitos (DELIZOICOV et al., 2011).

Destaca-se que a seleção dos conceitos científicos teve como ponto de partida a análise das falas dos alunos, moradores e professoras representadas no Quadro 2. Essas falas são reveladoras, no sentido de que é possível compreendê-las como uma expressão do conhecimento dos sujeitos acerca da realidade em que vivem. Nessas falas há uma elaboração de raciocínios, em que se articulam conceitos e juízos, sendo estes enunciados manifestados através de proposições (SILVA, 2004).

Cabe ressaltar que nesta fase da Redução Temática é importante incluir outros conhecimentos para além dos conceitos das ciências naturais (física, química e biologia), tais como aqueles envolvidos na história, sociologia, filosofia e antropologia. Por exemplo, 
discutir conceitos de reciclagem, coleta seletiva e consumo do lixo envolvem não apenas tratá-los sob o ponto de vista biológico, mas também abordá-los no contexto dos fundamentos da Educação Ambiental (EA) em uma perspectiva crítica, em que é preciso considerar as dimensões sociais, políticas e culturais indissociáveis da questão ambiental, em consonância com as políticas públicas brasileiras (BARBOSA, 2008; TORRES, 2010).

Quadro3: Terceira fase da Redução Temática.

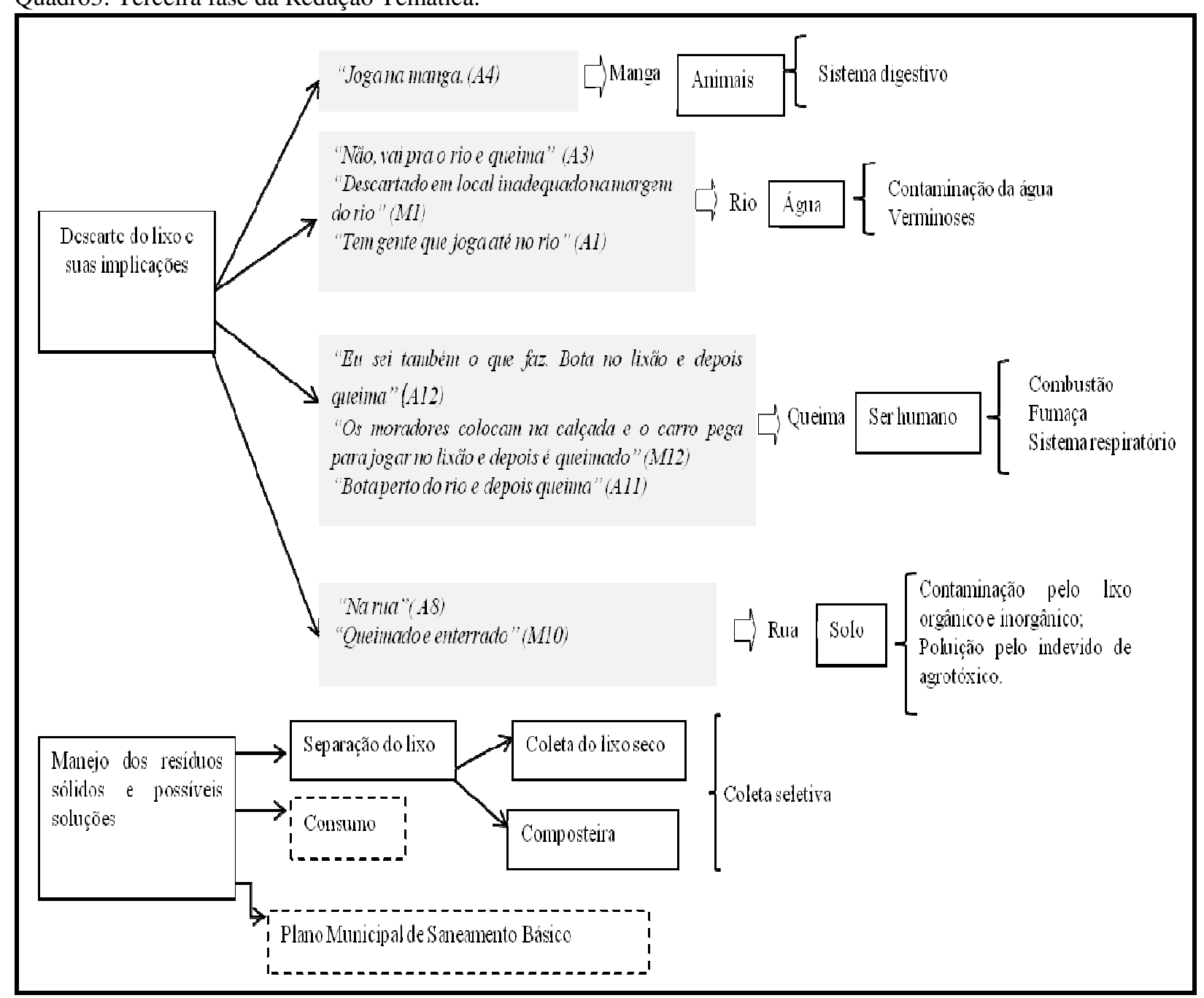

Fonte: Autores

\section{Planejamento das aulas a partir dos Momentos Pedagógicos}

Identificados os conteúdos e conceitos científicos necessários para compreensão do tema, foram elaboradas, em parceria com as professoras, as atividades didático-pedagógicas. Foi sugerida às professoras a possibilidade de organizar as aulas por meio dos Momentos Pedagógicos (DELIZOICOV et al., 2011), construídas a partir de uma adaptação da proposta de Silva (2004), em que o ponto de partida da sistematização das aulas eram falas de moradores, alunos e professoras, representativas de situações-limite, como ilustra o Quadro 4.

Chama-se a atenção que este é um exemplar de uma construção inicial do planejamento elaborado junto com as professoras, com intuito de apresentar como se deu a organização das atividades com base nos Três Momentos Pedagógicos. Destaca-se que este 
planejamento é parte da proposta e que a mesma envolve outros aspectos, por exemplo, após o planejamento da composteira há necessidade de ampliar a discussão enfatizando a participação coletiva e o compartilhamento das responsabilidades ambientais com diferentes instâncias, transcendendo a discussão apenas de iniciativas individuais.

Quadro 4: Quarta fase do processo de Redução Temática. Neste quadro, as expressões representam: PI (Problematização Inicial), OC (Organização do Conhecimento) e AC (Aplicação do Conhecimento).

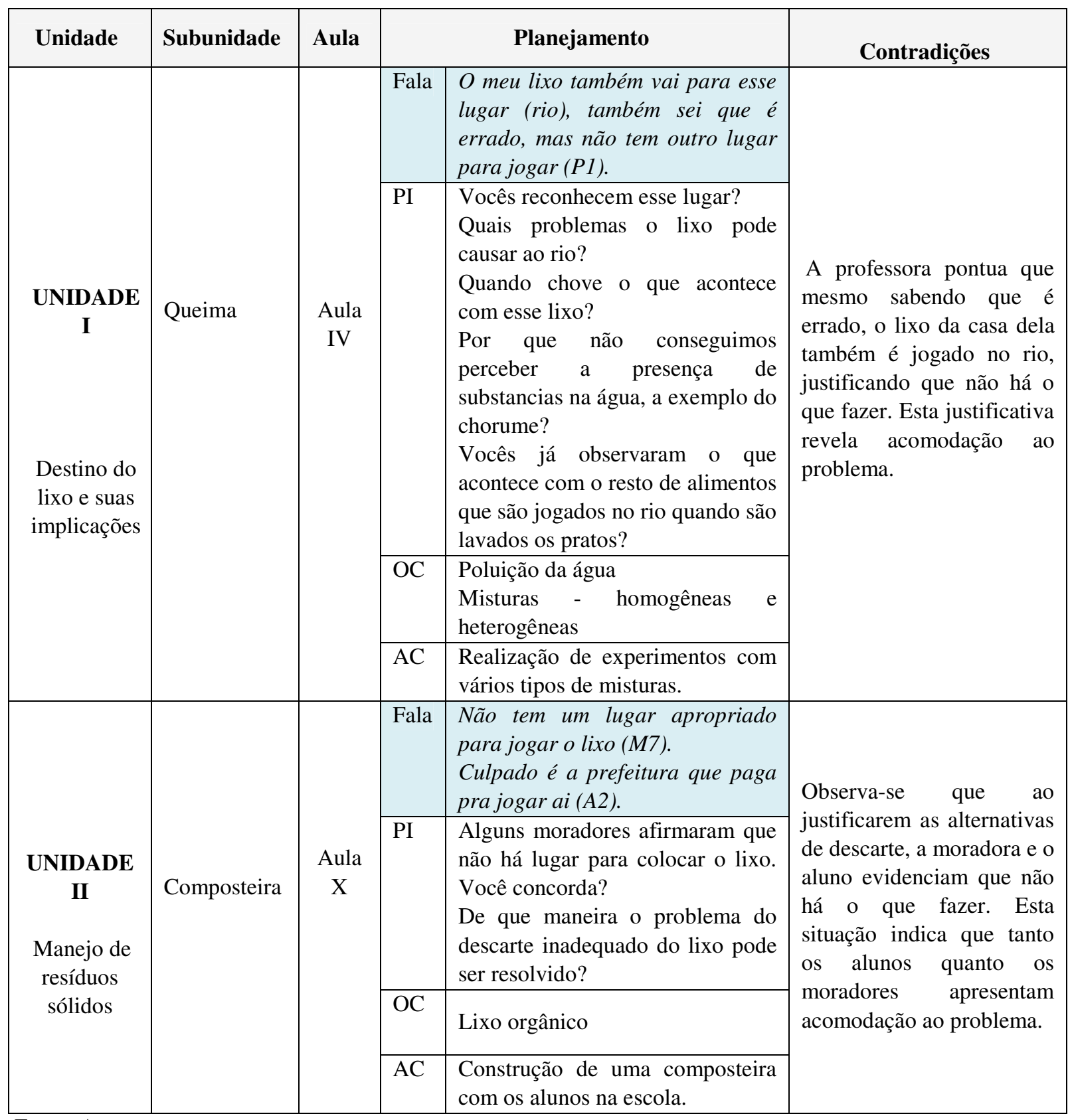

Fonte: Autores

Delizoicov et al. (2011) estruturam a dinâmica dos Três Momentos Pedagógicos como dinâmica de ação das atividades em sala de aula, os quais compreendem: 1) Problematização inicial (PI)): os alunos são desafiados a expor suas compreensões sobre determinadas situações; 2) Organização do Conhecimento (OC): são estudados os conhecimentos científicos necessários para a compreensão dos Temas Geradores e da problematização inicial; 3) Aplicação do Conhecimento (AC): aborda sistematicamente o conhecimento que 
vem sendo incorporado pelo aluno com a retomada das situações iniciais e a abordagem de novas situações. Chama-se atenção para o papel da OC, tendo em vista que é neste momento que os conteúdos e conceitos científicos selecionados na terceira fase da Redução Temática são abordados pelo professor para ajudar o estudante a compreender criticamente o problema em estudo.

No Quadro 4, observa-se que a partir de uma fala significativa reveladora de contradições sociais expressa pela comunidade local ou por algum aluno ou professora, estrutura-se os Momentos Pedagógicos. Assim, na PI várias questões foram elaboradas pelas professoras e pelo grupo de pesquisadores visando problematizar uma fala significativa. $\mathrm{Na}$ Organização do Conhecimento OC foram selecionados conteúdos importantes que auxiliariam os alunos a compreender criticamente o problema ou descodificar a fala representativa de uma contradição e, por fim, na AC foram selecionadas algumas práticas que ajudariam os estudantes a aplicarem seus conhecimentos apreendidos.

Durante esta última fase da Redução Temática as professoras parecem ter compreendido que, no contexto da perspectiva freireana, não é qualquer problematização que deverá ser realizada, mas sim aquela que leve em consideração o problema, traduzido no Tema Gerador (FREIRE, 1987), conforme relata P1:

A elaboração das questões referente à Problematização Inicial, porque não é qualquer questão, as questões devem ser elaboradas fazendo com que os alunos possam refletir sobre o tema abordado (P1 - grifo nosso).

Além disso, P1 acrescentou que:

Porque as questões favorecem o diálogo entre o professor e o aluno fazendo com que os professores percebam o conhecimento que os alunos já têm. Deixo eles a vontade porque é o momento que eles vão falar do conhecimento que eles já têm, já traz de casa. E esse conhecimento é trabalhado em sala de aula (P1).

Fica claro que P1 compreendeu o significado e relevância da problematização na apropriação do conhecimento, pois a mesma pontuou que as questões favorecem a interação em sala de aula, revelam o conhecimento que os alunos já obtêm, além de promover um novo conhecimento por meio da troca de experiências. Para Delizoicov (2001), esses aspectos são fundamentais, mas a problematização necessita ir além e proporcionar no sujeito a necessidade de "querer saber mais", aspecto que não foi constatado nas falas das professoras, o que indica que há necessidade da continuação de atividades desta natureza com as professoras, motivo pelo qual o planejamento das aulas deu-se também após o curso.

Em suma, esta última fase da Redução Temática refere-se ao planejamento das atividades didático-pedagógicas a serem trabalhadas com base nos Três Momentos Pedagógicos (DELIZOICOV et al., 2011), tendo sempre como referência uma fala representativa da situação-limite, relacionada ao Tema Gerador. 


\section{Considerações finais e alguns encaminhamentos}

Ao analisar o processo de Investigação Temática relacionado ao Tema Gerador "Para onde vai o lixo do meio rural de Iguaí-BA?", constatou-se que é por meio deste que a organização didático-pedagógica se concretiza de forma participativa e democrática envolvendo a articulação entre a multiciplicidade de vozes imersas na realidade investigada e os conhecimentos científicos.

Durante esse processo, foi possível concretizar junto às professoras um trabalho interdisciplinar entre os conhecimentos de diferentes áreas, ao selecionar conteúdos necessários para a compreensão do tema. Salienta-se, todavia, que convergentemente às ideias expressas por Ricardo (2005), tal interdisciplinaridade não deve ser entendida simplesmente como um trabalho de ação coletiva, que integra diversos olhares de diferentes áreas para o mesmo objeto de estudo. A interdisciplinaridade necessita surgir a partir da complexidade do objeto que se quer conhecer ou compreender que depende do grau de colaboração e integração entre as estruturas teóricas e metodológicas das áreas dos saberes envolvidos, possibilitando explorar os limites e as potencialidades de cada disciplina (RICARDO, 2005).

No que se refere, especificamente, à Redução Temática foi possível evidenciar quatro fases que envolvem este processo, tais como apresenta a figura 3.

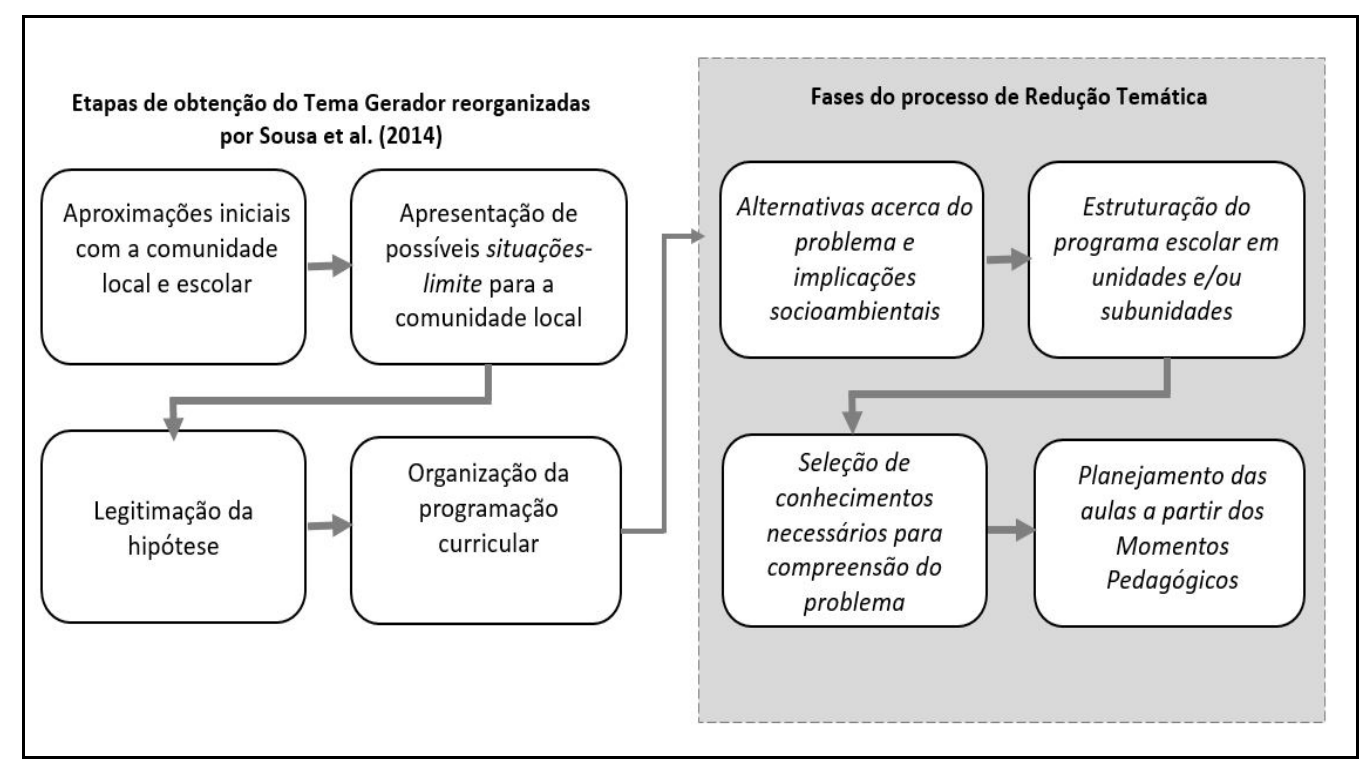

Figura 3: Fases da Redução Temática a partir das etapas de obtenção do Tema Gerador. Fonte: Autores

A figura 3 sintetiza o desenvolvimento das quatro fases que foram organizadas especificamente durante a quarta etapa do processo de investigação do Tema Gerador, denominada por Sousa et al. (2014) de Organização da Programação Curricular. Essas discussões se assemelham àquelas já apresentadas por Freire (1987), Delizoicov (1982; 1991), Delizoicov et al. (2011) e Silva (2004), contribuindo no sentido de apresentar com mais 
detalhes o processo de sistematização da Redução Temática no contexto da formação de professores. Tais detalhes fornecem subsídios teórico-práticos para pesquisadores da área e para professores da educação básica de como é possível desenvolver o processo de Redução Temática em fases para organizar o conteúdo programático e elaborar atividades didáticopedagógicas pautadas em Temas Geradores, contribuindo para que outros processos formativos sejam organizados e promovidos ou para que a perspectiva freireana possa ser desenvolvida por professores nas escolas.

Desta forma, este estudo contribui para evitar concepções reducionistas a respeito da Redução Temática como uma simples tarefa de selecionar conteúdos, conceitos científicos, conhecimentos e práticas, em que professores decidem aleatoriamente o que vai ser trabalhado em sala de aula. As quatro fases da Redução Temática, sistematizadas nessa pesquisa, revelaram que este processo consiste em uma atividade composta por diferentes etapas que se complementam e integram um processo mais amplo de estruturação curricular. Sob esta perspectiva, entende-se que o desenvolvimento da Redução Temática, bem como da Investigação Temática como um todo, envolve o desenvolvimento de uma práxis que a reestrutura, respeitando os pressupostos freireanos fundamentais, possibilitando o delineamento de subsídios mais claros para a sua efetivação. Em outras palavras, desenvolver o processo de Investigação Temática, portanto, envolve uma constante reorganização de suas etapas, influenciadas pelo contexto em que são desenvolvidas (SOUSA et al., 2014).

Constatou-se, também, que a estruturação da Redução Temática em quatro fases desencadeou um processo de desvelamento do tema do ponto de vista pedagógico. Isto é, o processo de redução do tema seguiu um movimento em espiral que permitiu que a cada cisão que o planejamento fosse se constituindo, proporcionando uma análise do ponto de vista conceitual-pedagógico articulado com o Tema Gerador.

Além disso, a sistematização das quatro fases constitui reflexo do trabalho colaborativo com as professoras, cujas fases foram se constituindo com o intuito de elucidar o processo de partir do Tema Gerador como referencial analítico-propositivo do programa escolar de ciências, área sobre a qual as professoras possuíam uma carência formativa. Sendo assim, tais fases também constituíram vias de problematização junto às professoras, no que se refere ao contato com outra lógica curricular.

Cabe, ainda, ressaltar que a Redução Temática necessita ser desenvolvida de modo articulado com as demais etapas da Investigação Temática, seja para a escolha dos conceitos e conteúdos escolares ou para o planejamento das atividades didático-pedagógicas. Essa relação entre o processo de seleção de um Tema Gerador e a organização de atividades didáticopedagógicas é importante para compreender como é possível construir currículos dinâmicos e críticos pautados nos pressupostos freireanos. 
Além disso, sinaliza-se para a relevância da articulação dos conhecimentos abordados com a percepção da comunidade escolar sobre o tema, tendo em vista a superação e compreensão ampla dos problemas inerentes à realidade. Em outras palavras, um planejamento pautado nos pressupostos freireanos não se restringe a abordagem do conteúdo programático, mas da relação que este conteúdo tem com os problemas relacionados à realidade dos alunos. Isto possibilita a promoção de um ensino que considere o saber científico e o saber dos educandos, bem como a formação de sujeitos críticos e participativos (FREIRE, 1987).

Considerar as diferentes vozes dos sujeitos, eleger um Tema Gerador, selecionar conhecimentos e práticas para a sua compreensão, problematizar o conhecimento do aluno são práticas complexas e inerentes a uma lógica de educação diferente daquelas comumente encontradas e praticadas pelas escolas. Para encontrar meios que atenuem o grau de complexidade da estruturação curricular é necessário estabelecer trabalhos colaborativos entre universidade, escola e comunidade, na medida em que juntos busquem superar os obstáculos e encontrar caminhos para a concretização de uma educação mais humana e transformadora. Atividades desenvolvidas e analisadas, seguindo esta proposta, podem ser encontradas em estudos de, por exemplo, Silva (2004), Lambach (2013), Torres et al. (2008), Sousa et al. (2016), Magalhães e Gehlen (2016) e Centa e Muenchen (2016).

\section{Referências}

ANGOTTI, J. A. Conceitos unificadores e ensino de física. Revista Brasileira de Ensino de Física, v. 15, n. 1 a 4, p. 191-198, 1993. Disponível em:

http://sbfisica.org.br/rbef/vol15a20.pdf. Acesso em: 26 Abr. 2016.

AULER, N.M.F; AULER,D. Conhecer e executar currículos: ampliando o processo formativo de educadores(as). In: AULER, N.M.F.; AULER. D. (orgs.). Concepção e execução do currículo no processo formativo de Licenciandos do PIBID. Curitiba: CRV, 2015. p. 13-40

\section{ARAÚJO, L. B. Os Três Momentos Pedagógicos como estruturantes de currículos.}

Dissertação de Mestrado. Programa de Pós-Graduação em Educação em Ciências: Química da vida e saúde. Santa Maria/RS: UFSM, 2015.

BARBOSA, L. C. Políticas públicas de educação ambiental numa sociedade de risco: tendências e desafios no Brasil. In: ENCONTRO NACIONAL DA ANPPAS, 4, 2008, Brasília - DF, Anais... Brasília - DF, 2008. Disponível em: http://portal.mec.gov.br/dmdocuments/publicacao11.pdf. Acesso em 11/07/2016.

CENTA, F.G.; MUENCHEN, C. O despertar de uma cultura de participação no trabalho com um Tema Gerador. Alexandria- Revista de Educação em Ciência e Tecnologia, v.9, n.1, p. 263-291, 2016. Disponível em: https://periodicos.ufsc.br/index.php/alexandria/article/view/1982-5153.2016v9n1p263. Acesso: 10 de julho de 2016. 
CHAGAS, E. Ensino de física para o curso técnico integrado em alimentos problematizado na região de Coxim. Dissertação de Mestrado. Programa de Pós-Graduação em Ensino de Ciências. Campo Grande/MS: UFMS, 2014.

DELIZOICOV, D. Conhecimento, Tensões e Transições. Tese de Doutorado. São Paulo: FEUSP, 1991.

DELIZOICOV, D. Problemas e Problematizações. In: PIETROCOLA, M. (org.). Ensino de Física: conteúdo, metodologia e epistemologia numa concepção integradora.

Florianópolis/SC: UFSC, 2001. p. 125-150.

DELIZOICOV, D; ANGOTTI, J. A.; PERNAMBUCO, M. M. C. Ensino de Ciências: fundamentos e métodos. $3^{\mathrm{a}}$ ed. São Paulo: Cortez, 2011.

FREIRE, P. Pedagogia do oprimido. 17 ed. Rio de Janeiro: Paz e Terra, 1987.

FREIRE, P. Extensão ou comunicação? 12. ed. Rio de Janeiro: Paz e Terra, 2002.

FURLAN, A. B. S.; RICCI, E. C.; GOMES, C. G. S.; SILVA, A. F. G. Abordagem temática no currículo de ciências: a perspectiva ético-critica na concepção de lixo como condição humana. In: ENCONTRO NACIONAL DE PESQUISA EM EDUCAÇÃO EM CIÊNCIAS, 8, 2011, Campinas/SP, Anais... Campinas/SP, 2011.

HALMENSCHLAGER, K. R. Abordagem de temas em ciências da natureza no ensino médio: implicações na prática e na formação docente. Tese de Doutorado em Educação Científica e Tecnológica - Universidade Federal de Santa Catarina, Florianópolis, 2014.

LAMBACH, M. Formação Permanente de Professores de Química da EJA na Perspectiva Dialógico-Problematizadora Freireana. Tese de Doutorado em Educação Científica e Tecnológica - Universidade Federal de Santa Catarina, Florianópolis, 2013.

MAGALHÃE, R. S. A Abordagem Temática Freireana na formação de professores de Ciências sob a óptica da Teoria da Atividade. Dissertação. PPGECFP: UESB, Jequié-BA, 2015.

MAGALHAES, R. S.; GEHLEN, S. T., 2016. Investigação Temática na formação de professores de Ciências em Pau Brasil-BA: compreensões acerca de um Tema Gerador. Ensaio: Pesquisa em Educação em Ciências, v.18, n. 2, p.147-169, maio-agosto, 2016. Disponível em: http://www.scielo.br/pdf/epec/v18n2/1983-2117-epec-18-02-00147.pdf. Acesso em: 05 de maio de 2016.

MORAES, R.; GALLIAZI, M. C. Análise Textual Discursiva. Ijuí: UNIJUÍ, 2007.

MUENCHEN, C.; AULER, D. Abordagem Temática: desafios na Educação de Jovens e Adultos. Revista Brasileira de Pesquisa em Educação em Ciências, v.7, n.3, 2007. Disponível em: http://revistas.if.usp.br/rbpec/article/view/61. Acesso em: 26 Abr. 2016.

PERNAMBUCO, M.M.C. A. Significações e realidade: conhecimento. In: PONTUSCHKA, N. N. (org). Ousadia no diálogo. 3 ed. São Paulo, Loyola, 2001. 
PONTUSCHKA, N. N. (org.). Ousadia no diálogo. 3 ed. São Paulo, Loyola, 2001.

RICARDO, E. C. Competências, interdisciplinaridade e contextualização: dos Parâmetros Curriculares Nacionais a uma compreensão para o ensino das ciências. Tese de Doutorado Universidade Federal de Santa Catarina, Florianópolis: UFSC, 2005.

SÃO PAULO, Cadernos de Formação, 1, 2 e 3. Série: Ação pedagógica na escola pela via da interdisciplinaridade. Secretaria Municipal de Educação. São Paulo: DOT/SMESP, 1990.

SÃO PAULO, Movimento de Reorientação Curricular: Ciências. Visão da Área. Documento 5. Secretaria Municipal de Educação. São Paulo: DOT/SME 1992.

SILVA, A. F. G. A construção do currículo na perspectiva popular crítica: das falas significativas às práticas contextualizadas. Tese de Doutorado. PUC, São Paulo, 2004.

SOLINO, A. P. S. Abordagem Temática Freireana e Ensino de Ciências por Investigação: contribuições para o Ensino de Ciências/Física nos anos iniciais. Dissertação. PPGECFP: UESB, Jequié-BA, 2013.

SOUSA, P.S.; BASTOS, A.P. S.; FIGUEIREDO, P. S. GEHLEN, S. T. Investigação Temática no Contexto do Ensino de Ciências: Relações entre a Abordagem Temática Freireana e a Práxis Curricular via Tema Gerador. Alexandria-Revista de Educação em Ciência e Tecnologia, v. 7, n.2, p. 155-177, novembro 2014. Disponível em:

https://periodicos.ufsc.br/index.php/alexandria/article/view/38222. Acesso em: 20 Abr. 2016.

SOUSA, P.S.; BASTOS, A.P. S.; FIGUEIREDO, P. S. GEHLEN, S. T. Tema Gerador e a relação universidade-escola: percepções de professoras de Ciências de uma escola pública em Ilhéus-BA. Alexandria-Revista de Educação em Ciência e Tecnologia, v.9, n.1, p. 3-29, 2016. Disponível em: https://periodicos.ufsc.br/index.php/alexandria/article/view/19825153.2016v9n1p3. Acesso em: 20 Abr. 2016.

STRIEDER, R.S.; CARAMELLO, G. W.; HALMENSCHLAGER, K. R.; FEISTEL, R. A. B.; GEHLEN, S. T. Abordagem de Temas na Pesquisa em Educação em Ciências: Pressupostos Teórico-Metodológicos. In: ENCONTRO NACIONAL DE PESQUISA EM EDUCAÇÃO EM CIÊNCIAS, 8, 2011, Campinas/ SP. Anais... Campinas/ SP, 2011.

TORRES, J. R. Educação Ambiental Crítico-Transformadora e Abordagem Temática Freireana. Tese de Doutorado em Educação Científica e Tecnológica - Universidade Federal de Santa Catarina, Florianópolis, 2010.

TORRES, J. R.; GEHLEN, S. T.; MUENCHEN, C.; GONÇALVES, F.P; LINDEMANN, R. H. GONÇALVES, F.J.F. Ressignificação curricular: contribuições da Investigação Temática e da Análise Textual Discursiva. Revista Brasileira de Pesquisa em Ensino de Ciência, v. 8, n. 2, 2008. Disponível em: https://seer.ufmg.br/index.php/rbpec/article/download/2220/1619. Acesso em: 20 Abr. 2016. 


\section{SOBRE OS AUTORES}

EDCLEIDE DA SILVA PEREIRA NOVAIS. Graduada em Pedagogia pela Faculdade de Educação Montenegro - FAM (2007). Especialista em Educação Infantil pela Universidade Estadual do Sudoeste da Bahia - UESB (2012). Mestre em Educação em Ciências pela Universidade Estadual de Santa Cruz - UESC (2015). Tem como principal tema de pesquisa o Ensino de Ciências, Educação do Campo e a Abordagem Temática Freireana.

KAMILLA NUNES FONSECA. Graduada em Pedagogia pela Universidade Estadual de Santa Cruz - UESC (2014). Mestranda do Programa de Pós Graduação em Educação em Ciências pela Universidade Estadual de Santa Cruz (UESC), bolsista CAPES. Tem como principal tema de pesquisa o Ensino de Ciências nos anos inicias, relações entre as ideias de Milton Santos e Paulo Freire e Abordagem Temática Freireana.

ANA PAULA SOLINO BASTOS. Graduada em Pedagogia pela Universidade Estadual de Santa Cruz - UESC (2011) e mestrado em Educação em Ciências e Matemática pela Universidade Estadual do Sudoeste da Bahia - UESB (2013), Doutoranda do Programa de Pós-Graduação em Educação da Universidade de São Paulo (FEUSP). Pesquisa na área de Educação Científica, em especial nos seguintes temas: Ciências/Física nos Anos Iniciais, Abordagem Temática Freireana, Abordagem histórico-cultural e Ensino de Ciências por Investigação.

POLLIANE SANTOS DE SOUSA. Graduada em Licenciatura em Física pela Universidade Estadual de Santa Cruz - UESC (2013), Mestre em Educação em Ciências pela Universidade Estadual de Santa Cruz - UESC (2015). Doutoranda do Programa de Pós-Graduação em Educação Científica e Tecnológica da Universidade Federal de Santa Catarina (UFSC). Tem como principal tema de pesquisa o Ensino de Ciências/Física, Questões sócio-científicas e a Abordagem Temática Freireana.

ROGER MAGALHÃES DA SILVA. Graduado em Licenciatura em Física pela Universidade Estadual de Santa Cruz (UESC), 2013, e mestre em Ensino de Ciências e Matemática pelo Programa de Pós-Graduação em Educação Científica e Formação de Professores (PPGECFP) da Universidade Estadual do Sudoeste da Bahia (UESB), 2015. Tem como principal tema de pesquisa o ensino de Ciências/Física, a perspectiva histórico-cultural da Teoria da Atividade e Abordagem Temática Freireana.

SIMONI TORMÖHLEN GEHLEN. Graduada em Física Licenciatura Plena pela Universidade Federal de Santa Maria (2002), mestrado em Educação nas Ciências pela Universidade Regional do Noroeste do Estado do Rio Grande do Sul - UNIJUÍ (2006) e doutorado em Educação Científica e Tecnológica pela Universidade Federal de Santa Catarina - UFSC (2009). Atualmente é professora do curso de Licenciatura em Física da Universidade Estadual de Santa Cruz - UESC e do Programa de Pós Graduação em Educação em Ciências desta universidade. Tem experiência na área de Educação, com ênfase em Ensino de Ciências/Física, atuando principalmente nos seguintes temas: Práticas Freireanas no Ensino de Ciências, aproximações entre as ideias de Lev S. Vygotsky e Paulo Freire, Situação de Estudo, Abordagem Temática Freireana.

Recebido: 13 de julho de 2016.

Aceito: 10 de novembro de 2016. 